\title{
Small hive beetle, Aethina tumida, populations I: Infestation levels of honeybee colonies, apiaries and regions*
}

\author{
Sebastian SPIEWOK $^{\mathrm{a}}$, Jeff S. PETTIS ${ }^{\mathrm{b}}$, Michael DUNCAN $^{\mathrm{c}}$, Robert SPOONER-HART $^{\mathrm{c}}$, \\ David WESTERVELT ${ }^{\mathrm{d}}$, Peter NEUMANN ${ }^{\mathrm{e}-\mathrm{g}}$
}

\footnotetext{
${ }^{a}$ Institut für Biologie, Martin-Luther-Universität Halle-Wittenberg, Hoher Weg 4, 06099 Halle (Saale), Germany

${ }^{\mathrm{b}}$ USDA-ARS Bee Research Laboratory, Beltsville, MD 20705, USA

${ }^{c}$ Centre for Plant and Food Science, University of Western Sydney, Penrith South, NSW 1797, Australia

${ }^{\mathrm{d}}$ Florida Department of Agriculture, Division of Plant Industry, Gainesville, FL 32614, USA

e Swiss Bee Research Centre, Agroscope Liebefeld-Posieux Research Station ALP, 3003 Bern, Switzerland

${ }^{f}$ Department of Zoology and Entomology, Rhodes University, Grahamstown 6140, South Africa

${ }^{g}$ Eastern Bee Research Institute of Yunnan Agricultural University, Kunming, China
}

Received 27 April 2007 - Revised 1 October 2007 - Accepted 10 October 2007

\begin{abstract}
The small hive beetle (SHB) is a parasite and scavenger of honeybee colonies. Here we provide the first comprehensive systematic data on colony infestation levels with adult SHB for 226 colonies at 31 apiaries in South Africa, Australia, Florida and Maryland. Inside colonies, SHB distribution was influenced by the presence of bees with more SHB in the brood nest in the absence of bees. SHB distribution among colonies at an apiary was different from a random distribution but colony phenotypes (number of bees, amount of brood or stores) did not influence infestation levels. Apiaries next to large scale honey extraction facilities (honey houses) showed higher infestation levels and regions with more damage had higher SHB population levels. Consequently, methods of reducing SHB populations, such as the removal of dead colonies and the prevention of SHB reproduction in honey houses, seem to be important for pest management.
\end{abstract}

Aethina tumida / Apis mellifera / honeybees / infestation level / small hive beetle

\section{INTRODUCTION}

The small hive beetle (SHB), Aethina tumida Murray, native to sub-Saharan Africa (Lundie, 1940), is a parasite and scavenger of honeybee (Apis mellifera L.) colonies. Escaping its native range, SHB has become an invasive species in North America and Australia (Neumann and Elzen, 2004). While SHB are usually only a minor pest in African colonies (Lundie, 1940), they have caused considerable losses to US apiculture, with Florida appearing

Corresponding author: S. Spiewok,

S.Spiewok@web.de

* Manuscript editor: Marla Spivak to be the most severely affected state (Elzen et al., 2002).

Massive SHB infestations have been reported from US colonies (Elzen et al., 1999). So far, only minimal damage and low numbers of adult SHB per colony have been reported from Australia (Benecke, 2003; White, 2004) although there have been observations of acute damage in some areas since 2001 (MD unpublished). This situation in Australia seems to have changed recently (Spiewok, 2006).

Although the damage in the US boosted research on this pest, a systematic survey of SHB infestation levels in commercial colonies has not yet been conducted. This seems surprising 
because quantitative diagnosis is crucial for integrated pest management (IPM) to set an action threshold and thereby restricting the usage of conventional chemical treatments (Binns and Nyrop, 1992). The aim of the present study is to provide some of the baseline data lacking on SHB infestation levels. For this purpose, SHB were collected from colonies in South Africa, Australia and the USA while recording different factors that might influence SHB numbers.

A relationship between SHB population levels and the observed losses in the respective areas seems possible. We assumed that a high SHB pressure on host colonies may be one reason for losses and expected regions with higher losses (Florida and Australia) to suffer from higher infestation levels than those which experienced no or only moderate damage (South Africa, Maryland).

Lundie (1940) already noted that an apiary might harbour many SHB while a neighbouring one showed low numbers. Accordingly, we supposed that apiaries of one region are not equally infested due to different environmental factors such as soil moisture (Schmolke, 1974; Ellis et al., 2004b) or local beekeeping facilities. For example, the occurrence of SHB mass reproduction in honey extraction facilities (honey houses) (Lundie, 1940; Schmolke, 1974; Eischen et al., 1999) might lead to higher infestation levels in adjacent apiaries.

Within an apiary, SHB can choose between several potential hosts. Since SHB are attracted to volatiles of honeybees and their stores (Elzen et al., 1999; Suazo et al., 2003; Torto et al., 2005), the infestation level of a colony might be influenced by its phenotype. Stronger colonies might harbour more SHB than weaker ones, because larger honeybee groups are more attractive to SHB than smaller ones (Suazo et al., 2003). Ellis and Delaplane (2006) investigated the potential influence of colony phenotypes on SHB infestation levels. However, they surveyed nucleus colonies, which only have small variances in colony parameters and thus may have masked the full potential impact of colony phenotypes on SHB infestation levels. Therefore, we extended the study to commercial colonies with a higher phenotypic variance.

Inside the nest, SHB seem to aggregate at certain hiding or rendezvous sites (Lundie, 1940; Schmolke, 1974). Since bee brood is an oviposition substrate (Ellis et al., 2004a) and the favourite food source (Elzen et al., 2000), the brood nest might be the preferred withinhive location of SHB. However, Schmolke (1974) found only low SHB numbers on the combs of an African colony. Worker aggression may drive SHB to the rim of the nest, thereby inducing aggregations in peripheral hiding places. Since African workers were reported to be more aggressive against adult SHB than European ones (Elzen et al., 2001), less SHB might roam in their brood nests.

The data also may help determine an infestation level threshold, which may cause the decline and collapse of a colony, as in case of the mite Varroa destructor (Martin, 2001) by analysing bee/SHB ratios in the colonies. Knowledge about factors influencing infestation levels and possibly colony breakdowns would be an important variable for the control of SHB.

\section{MATERIALS AND METHODS}

\subsection{Research locations}

If not mentioned otherwise, SHB always indicates adult beetles in the text. SHB infestation levels were assessed in a total of 226 honeybee colonies among 31 apiaries in different parts of South Africa in January/February 2006, in Australia (Hawkesbury Area; NSW) in October/November 2005 and in the USA in Florida (Umatilla) from June-August 2004 as well as in Maryland in July/August 2005. For simplification, the term "regions" is used in the following text for Florida, Maryland, Australia and South Africa. All investigated colonies were chosen randomly, and no dead colonies were included into the analyses. However, the number of colonies with typical signs of former or current SHB mass reproduction (Lundie, 1940) was also noted for every apiary. None of the screened apiaries had been treated to control SHB for at least two months prior to the investigation. 


\subsection{Visual colony inspections}

All colonies were visually screened for all life stages of SHB in exactly the same way. Before a hive was opened, it was removed from its original position and replaced by an empty box. If the hive consisted of more than one box, the upper box was removed from the lower one and stored on a reversed lid, so that no bees or SHB could escape while working on the lower box. Each comb was removed separately and examined carefully for SHB, which were immediately collected with a mouth-aspirator. After the 1st inspection of a comb, the bees were shaken into the new box and then the comb was screened for a 2 nd time for possibly missed SHB due to their covering by bees. SHB were additionally driven out of possible hiding places by shaking the comb and blowing with the aspirator into the cells. Afterwards, the comb was placed into the new box. When all combs were evaluated, the former box and the bottom board were also screened. Finally, the new bottom board was screened for SHB that may have fallen down from the comb while the bees were being shaken off. Additionally, colony phenotypes were evaluated at most apiaries using the Liebefelder estimation method (Imdorf et al., 1987). For a possible threshold determination, the bee density and the bee/SHB ratio were determined. The number of screened colonies per apiary depended on the accessibility of colonies and local weather conditions.

\subsection{Controls}

To estimate the numbers of SHB that might have been missed during visual inspection, specific SHB numbers $(42,88,98,112,135,172)$, unknown to the investigator, were introduced into six SHB-free colonies in Maryland. Then, SHB were given one hour to disperse inside the colonies before the control inspection started.

\subsection{Distribution of SHB inside colonies}

The distribution of adult SHB within colonies was assessed in Florida ( $\mathrm{n}=65$ colonies) and South Africa ( $n=36$ colonies). Five of the African colonies were artificially infested with 700 adult SHB to achieve comparable SHB numbers to the ones in Florida (see results) and screened one week later. To control for the influence of honeybee workers on the distribution of adult SHB in colonies, five-frame nucleus boxes $(n=8)$ were installed in Florida with capped brood and pollen/honey combs but without any adult bees. The control boxes were then infested with a varying number of adult SHB $(5,15,25,35,45,65,85$ and 125$)$ to simulate the variation in natural infestation levels and the entrances were closed. After $24 \mathrm{~h}$, the SHB were recaptured. The percentages of SHB on the combs in general and in the brood nest $(=$ combs at least $50 \%$ covered with brood cells) were compared between the European and African colonies and the controls using Kruskal-Wallis tests (KWT), followed by Mann-Whitney-U tests (MWU, adjusted $\alpha=0.017$ ).

\subsection{Infestation levels of colonies: Influence of colony phenotypes}

To test whether SHB distribution was random, the observed distribution of SHB among five apiaries with ten to 19 colonies per apiary was compared to a Poisson distribution using $\chi^{2}$-goodnessof-fit tests. In case of a non-random distribution, a multiple regression was run between colony size, amount of brood, honey or pollen and number of SHB, to detect a possible influence of colony phenotype on SHB infestation levels.

\subsection{Infestation levels of apiaries: Influence of nearby honey extraction facilities (honey houses)}

The infestation levels of apiaries within the same region were analysed for differences with KWT and multiple comparisons. To discover a possible influence of a nearby honey house on the infestation level of a whole apiary, two groups of apiaries were investigated in Florida. One comprised five apiaries adjacent to a honey house $(<100 \mathrm{~m}$ away; $\mathrm{H}_{F L} 1-\mathrm{H}_{F L} 5$ ) and the other, four more distant apiaries ( $\geqslant 2.5 \mathrm{~km}$ away from the nearest honey house; $\mathrm{A}_{F L} 1-\mathrm{A}_{F L} 4$; Fig. 1). The exact location of each apiary was assessed via GPS.

\subsection{Infestation levels of apiaries in different regions}

For this analysis, the apiaries of the respective regions were not combined due to significant differences in their infestation levels (see results). We 


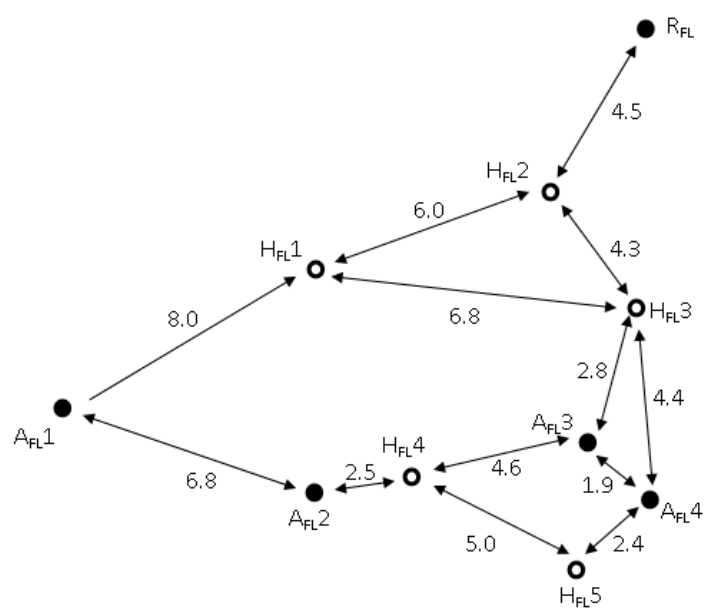

Figure 1. Investigated apiaries in Umatilla, Florida, USA ( $\circ=$ apiaries $<100 \mathrm{~m}$ from honey houses; $\bullet=$ apiaries $>2.5 \mathrm{~km}$ from honey houses). Data from apiary $\mathrm{R}_{F L}$ were only used for correlation analysis (Tab. III).

separated the apiaries in each region into two groups according to colony infestation levels. All highly infested apiaries in one region formed the HI-group (high infested group), while the low infested ones formed the LI-group (low infested group). By running a KWT for every group, their integrities were confirmed (no significant differences between apiaries of the same group). The terms "high" and "low" infested are used in the context of each respective region. Thus, a high infested apiary in one region might show lower SHB numbers compared to a low infested apiary in another region. Therefore, the infestation levels of the different regions were compared by analysing the confirmed HI- and LI-groups with a KWT and MWU tests as post hoc comparisons. The adjusted level of significance started with $\alpha=0.00179$ and increased stepwise according to the Bonferroni-Holm procedure. Additionally, the bee/SHB ratios of the HI-groups of Maryland and Florida were compared by analysing the $l g$-transformed data with a t-test (excluding noninfested colonies) as an indicator for parasite pressure in these regions.

\section{RESULTS}

\subsection{General observations}

In addition to adult SHB, SHB eggs were only observed in two colonies in Australia. SHB larvae ( 50-100) were found only in three Australian colonies on combs and in three African ones in the debris ( $<50$ larvae). Colonies abandoned by the bees had SHB larvae on the combs in South Africa $(\mathrm{N}=1)$, Australia $(\mathrm{N}=10)$ and Florida $(\mathrm{N}=13)$ but not in Maryland. The numbers of dead colonies are shown in Table I. The highest numbers of SHB found in vital colonies were 699 in Florida, 420 in Australia, 96 in South Africa and 54 in Maryland. The lowest bee density in an infested colony without any signs of damage was found at the apiary $\mathrm{A}_{F L} 2$ in Florida with 10 bees $/ \mathrm{dm}^{2}$ comb area and 27 bees/SHB $(\mathrm{N}=64 \mathrm{SHB})$.

\subsection{Controls}

All SHB numbers are medians [1st; 3rd quartile]. During the control survey an average of $9[8 ; 10]$ SHB were not found corresponding to $8.4 \%[6.4 ; 11.5]$. The total number of introduced SHB neither correlated with the number $\left(\mathrm{r}_{s}=0.46 ; \mathrm{t}_{4}=1.05 ; P=0.354\right)$ nor the percentage of missed SHB $\left(\mathrm{r}_{s}=0.77\right.$; $\left.\mathrm{t}_{4}=2.42 ; P=0.072\right)$.

\subsection{Distribution of SHB inside colonies}

The percentages of adult SHB in different hive parts of European and African colonies and in the controls are shown in Table II. In 
Table I. For each apiary, numbers of all colonies, screened (Scr.) and dead ones as well as average infestation levels (median [1st; 3rd quartile]) are shown. Also, the affiliation to the respective LI- or HI-group is given with the statistical values showing the integrity of the group (Kruskal Wallis test $=\mathrm{KWT}$ ). $\mathrm{R}_{F L}$ was not included into the group analyses. Different letters indicate significant differences between the average regional infestation levels (Mann-Whitney $\mathrm{U}$ tests, adjusted $\alpha=0.00179$ ).

\begin{tabular}{|c|c|c|c|c|c|c|c|}
\hline \multirow{2}{*}{ Region } & \multirow{2}{*}{ Apiary } & \multicolumn{3}{|c|}{$\mathrm{N}$ colonies } & \multirow{2}{*}{$\begin{array}{c}\text { Infestation } \\
\text { level }\end{array}$} & \multirow{2}{*}{$\begin{array}{l}\text { LI/HI- } \\
\text { Group } \\
\text { KWT }\end{array}$} & \multirow{2}{*}{$\begin{array}{c}\text { Regional } \\
\text { infestation level }\end{array}$} \\
\hline & & Total & Scr. & Dead & & & \\
\hline \multirow{8}{*}{$\begin{array}{l}\text { South } \\
\text { Africa }\end{array}$} & $\mathrm{A}_{\mathrm{SA}} 1$ & 54 & 13 & 0 & $6[2 ; 7]$ & \multirow{4}{*}{$\begin{array}{c}\text { LI } \\
\mathrm{H}=5.1 \\
P=0.17\end{array}$} & \multirow{4}{*}{$6[4 ; 9]^{\mathrm{d}}$} \\
\hline & $\mathrm{A}_{\mathrm{SA}} 2$ & 24 & 6 & 0 & $14[7 ; 17]$ & & \\
\hline & $\mathrm{A}_{\mathrm{SA}} 3$ & 15 & 6 & 0 & $5[3 ; 7]$ & & \\
\hline & $\mathrm{A}_{\mathrm{SA}} 4$ & 27 & 5 & 0 & $6[5 ; 8]$ & & \\
\hline & $\mathrm{A}_{\mathrm{SA}} 5$ & 24 & 10 & 1 & $29[21 ; 38]$ & $\mathrm{HI}$ & \multirow{4}{*}{$28[20 ; 37]^{\mathrm{b}}$} \\
\hline & $\mathrm{A}_{\mathrm{SA}} 6$ & 48 & 6 & 0 & $30[28 ; 67]$ & $\mathrm{H}=1.3$ & \\
\hline & $\mathrm{A}_{\mathrm{SA}} 7$ & 18 & 6 & 0 & $25[20 ; 47]$ & $P=0.73$ & \\
\hline & $\mathrm{A}_{\mathrm{SA}} 8$ & 9 & 9 & 0 & $24[17 ; 33]$ & & \\
\hline \multirow{5}{*}{ Australia } & $\mathrm{A}_{\mathrm{AU}} 1$ & 48 & 10 & 3 & $31[17 ; 41]$ & LI & \multirow{4}{*}{$29[19 ; 45]^{\mathrm{b}}$} \\
\hline & $\mathrm{A}_{\mathrm{AU}} 2$ & 80 & 6 & 0 & $31[20 ; 36]$ & $\mathrm{H}=3.7$ & \\
\hline & $\mathrm{A}_{\mathrm{AU}} 3$ & 52 & 11 & 5 & $38[25 ; 61]$ & $P=0.30$ & \\
\hline & $\mathrm{A}_{\mathrm{AU}} 4$ & 24 & 10 & 0 & $22[11 ; 36]$ & & \\
\hline & $\mathrm{A}_{\mathrm{AU}} 5$ & 8 & 5 & 2 & $321[48 ; 323]$ & $\mathrm{HI}$ & $321[48 ; 323]^{\mathrm{a}}$ \\
\hline \multirow{10}{*}{ Florida } & $\mathrm{A}_{\mathrm{FL}} 1$ & 22 & 5 & 0 & $6[5 ; 10]$ & & \multirow{6}{*}{$15[8 ; 32]^{\mathrm{c}}$} \\
\hline & $\mathrm{A}_{\mathrm{FL}} 2$ & 40 & 6 & 0 & $22[13 ; 44]$ & LI & \\
\hline & $\mathrm{A}_{\mathrm{FL}} 3$ & 24 & 8 & 0 & $14[6 ; 32]$ & $\mathrm{H}=5.6$ & \\
\hline & $\mathrm{A}_{\mathrm{FL}} 4$ & 32 & 10 & 0 & $13[8 ; 31]$ & $P=0.06$ & \\
\hline & $\mathrm{H}_{\mathrm{FL}} 2$ & 18 & 5 & 0 & $36[25 ; 53]$ & & \\
\hline & $\mathrm{H}_{\mathrm{FL}} 3$ & 24 & 6 & 0 & $13[9 ; 21]$ & & \\
\hline & $\mathrm{H}_{\mathrm{FL}} 1$ & 74 & 19 & 7 & $148[101 ; 275]$ & $\mathrm{HI}$ & \\
\hline & $\mathrm{H}_{\mathrm{FL}} 4$ & 4 & 4 & 0 & $148[120 ; 219]$ & $\mathrm{H}=6.9$ & $168[116 ; 327]^{\mathrm{a}}$ \\
\hline & $\mathrm{H}_{\mathrm{FL}} 5$ & 80 & 5 & 5 & $344[321 ; 542]$ & $P=0.23$ & \\
\hline & $\mathrm{R}_{\mathrm{FL}}$ & 11 & 10 & 1 & $88[57 ; 104]$ & - & \\
\hline \multirow{8}{*}{ Maryland } & $\mathrm{M}_{\mathrm{MD}} 1$ & 36 & 5 & 0 & $0[0 ; 0]$ & \multirow{4}{*}{ LI } & \multirow{4}{*}{$0[0 ; 0]^{\mathrm{e}}$} \\
\hline & $\mathrm{M}_{\mathrm{MD}} 2$ & 16 & 5 & 0 & $0[0 ; 0]$ & & \\
\hline & $\mathrm{M}_{\mathrm{MD}} 3$ & 46 & 6 & 0 & $0[0 ; 0]$ & & \\
\hline & $\mathrm{M}_{\mathrm{MD}} 4$ & 48 & 5 & 0 & $0[0 ; 0]$ & & \\
\hline & $\mathrm{A}_{\mathrm{MD}} 1$ & 48 & 6 & 0 & $6[3 ; 10]$ & $\mathrm{HI}$ & \multirow{4}{*}{$4[2 ; 9]^{\mathrm{d}}$} \\
\hline & $\mathrm{A}_{\mathrm{MD}} 2$ & 20 & 6 & 0 & $2[1 ; 4]$ & $\mathrm{H}=3.6$ & \\
\hline & $\mathrm{A}_{\mathrm{MD}} \mathrm{X}$ & 18 & 7 & 0 & $6[5 ; 10]$ & $P=0.30$ & \\
\hline & $\mathrm{A}_{\mathrm{MD}} \mathrm{Y}$ & 5 & 5 & 0 & $2[1 ; 3]$ & & \\
\hline
\end{tabular}


Table II. Bee density, bees/SHB ratio, total number and distribution of SHB in European and African honeybee colonies and in the controls are shown (medians [1st; 3rd quartile]). Different letters indicate significant differences (Mann-Whitney $\mathrm{U}$ tests, adjusted $\alpha=0.016$ ).

\begin{tabular}{cccc}
\hline & European colonies & African colonies & Controls \\
\hline Bee density $\left(\right.$ bees $\left./ \mathrm{dm}^{2}\right)$ & $51[38 ; 63]^{\mathrm{a}}$ & $52[34 ; 73]^{\mathrm{a}}$ & $0[0 ; 0]^{\mathrm{b}}$ \\
Bee/SHB ratio & $288[67 ; 1365]^{\mathrm{a}}$ & $151[88 ; 294]^{\mathrm{a}}$ & $0[0 ; 0]^{\mathrm{b}}$ \\
Total number of SHB & $36[11 ; 93]^{\mathrm{a}}$ & $38[24 ; 63]^{\mathrm{a}}$ & $40[23 ; 70]^{\mathrm{a}}$ \\
$\%$ brood combs in a colony & $50[36.8 ; 66.7]^{\mathrm{a}}$ & $56[42 ; 71]^{\mathrm{a}}$ & $50[40 ; 60]^{\mathrm{a}}$ \\
$\%$ SHB on combs in total & $52[31 ; 86]^{\mathrm{a}}$ & $56[0 ; 80]^{\mathrm{a} b}$ & $85[77 ; 94]^{\mathrm{b}}$ \\
$\%$ SHB in brood nest* & $14[4 ; 25]^{\mathrm{a}}$ & $0.1[0 ; 12]^{\mathrm{b}}$ & $80[56 ; 90]^{\mathrm{c}}$ \\
\hline
\end{tabular}

* Combs with at least $50 \%$ brood cells.

the controls, a significant higher percentage of SHB were roaming in the brood nests than in both European $(\mathrm{U}=21.5 ; P<0.001)$ and African colonies $(\mathrm{U}=2 ; P<0.001)$. Furthermore, the percentage of SHB found in the brood nests of European colonies was significantly higher than in African ones $(U=672$; $P<0.001)$.

\subsection{Infestation levels of colonies: influence of colony phenotypes}

At all apiaries, the distribution of SHB among colonies was significantly different from a Poisson distribution (Tab. III; Fig. 2). However, no significant regressions were found between colony phenotypes and SHB infestation levels (Tab. III; Fig. 3).

\subsection{Infestation levels of apiaries}

In all regions, infestation levels were significantly different between local apiaries (Tab. I). Half of the apiaries in Maryland were not infested $(\leqslant 1 \mathrm{SHB})$, while in the other regions each apiary harboured SHB. In Florida, no differences were found between infestation levels of apiaries distant from a honey house $\left(\mathrm{H}_{3}=3.42 ; P=0.331\right)$, but three out of five apiaries adjacent to a honey house $\left(\mathrm{H}_{F L} 1\right.$, $\mathrm{H}_{F L} 4$ and $\mathrm{H}_{F L}$ 5) had a significant higher infestation level than did the remote ones $(\mathrm{Z} \leqslant 3.18$; $P<0.022$ ).

The average infestation levels of all LI- and HI-groups of all regions as well as their statistical confirmation are given in Table I. There were significant differences between the regions, with the HI-groups of Florida and Australia showing highest infestation levels. The bee/SHB ratio of the HI-group of Florida (33 $[28 ; 63])$ was significantly smaller than the respective group of Maryland (970 [436; 1870]; $\left.\mathrm{t}_{41}=10.80 ; P<0.001\right)$.

\section{DISCUSSION}

This study provides the first extensive data for SHB infestation levels in honey bee colonies across three continents. We found higher infestation levels in Florida and Australia compared to those in South Africa or Maryland. However, apiary infestation levels differed within these regions with more SHB found in apiaries near large-scale honey houses. Colony infestation levels were not influenced by the respective colony phenotypes.

Inside colonies, our data suggest that the distribution of SHB is influenced by presence of worker bees. The percentages of adult SHB in the brood nests and on combs in general were significantly higher in the controls without honeybees compared to the test colonies. Honeybee workers might actively reject intruding SHB from the nest, as suggested earlier (Lundie, 1940). In both European and African colonies, very few SHB were found in the brood nest, indicating a particular protection of the brood nest. Interestingly, African colonies showed significantly fewer SHB in the brood nest compared to European ones. Since neither the size of the brood nest nor the total number of SHB was significantly different between European and African colonies, 


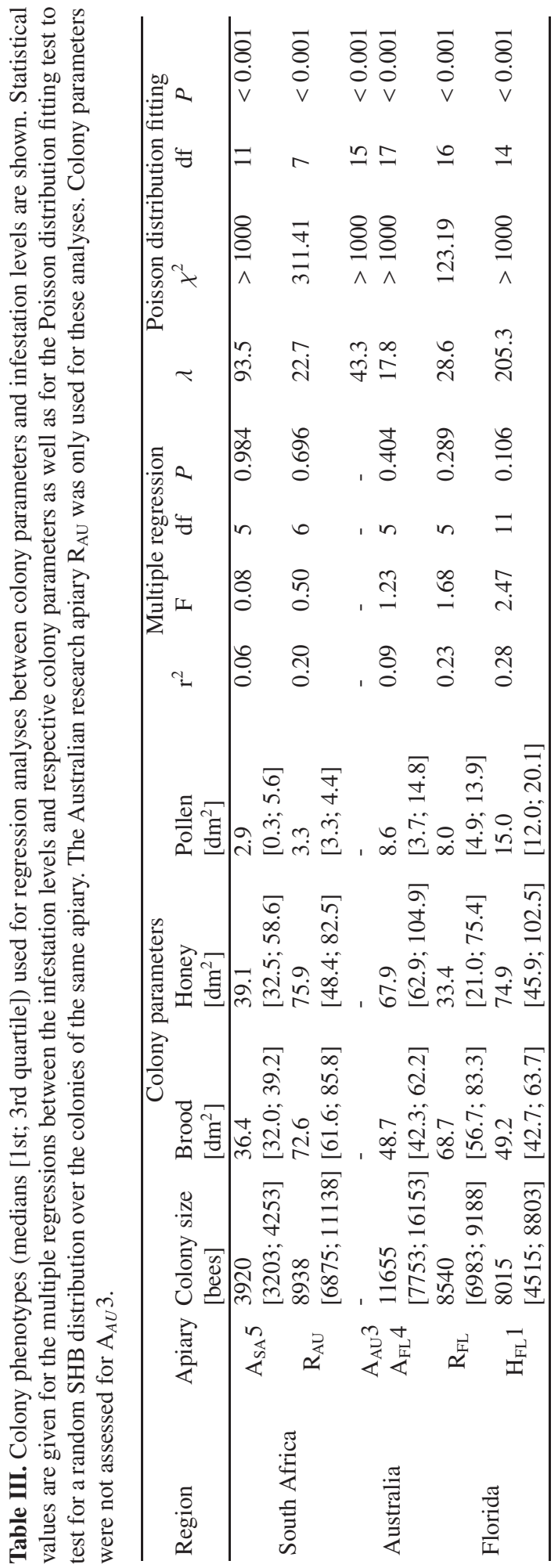


the higher percentages of SHB in European brood nests cannot be explained by these factors. An explanation might be the higher aggression of African workers towards SHB (Elzen et al., 2001). Moreover, climatic conditions and different behaviour of SHB in the US and in Africa might have influenced the observed distribution. The hot and humid conditions in Florida during the inspections might have driven a large proportion of workers out of the colonies, thereby facilitating the intrusion of the brood nests by SHB. The higher proportions of SHB in the brood nests might facilitate colony collapses in Florida.

The non-random distribution of SHB over the colonies within the same apiary suggests that some colonies are more attractive to SHB than others. However, SHB infestation levels did not correlate with any of the evaluated colony parameters; this is consistent with a previous study by Ellis and Delaplane (2006) on nucleus colonies. Colony volatiles might serve as cues for host finding (Elzen et al., 1999; Suazo et al., 2003; Torto et al., 2005), but appear to play a minor role only in host attractiveness. The strong bouquet of a whole colony might not enable any quantitative discrimination by SHB. Furthermore, fermentation products of beetle-associated yeast are attractive to SHB and might cause aggregations (Torto et al., 2007). However, it remains to be shown to which extent fermentation actually takes place in SHB infested but otherwise healthy colonies, especially in the absence of feeding SHB larvae. It is possible that aggregation pheromones are involved in SHB host finding, as is known from other Nitidulidae (Bartelt, 1999). To overcome host defence, SHB might use a mass attack strategy as is known in Scolytidae, such as the bark or pine beetles (Person, 1931; Thalenhorst, 1958), by using pheromones or invading as swarms (Tribe, 2000). However, despite intensive research, such pheromones have not yet been identified (Torto et al., 2007).

Our data show that honey houses can increase infestation levels in neighbouring apiaries. Those honey houses with highly infested adjacent apiaries were large scale operations with ongoing honey extraction. They were easily accessible for adult SHB and

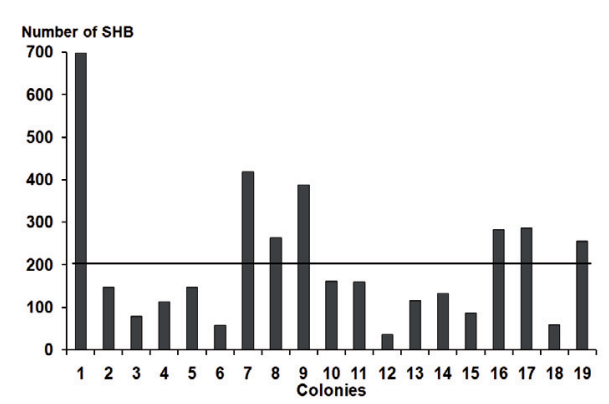

Figure 2. Example of unequal and non-random SHB distribution over colonies at an apiary $\left(\mathrm{H}_{F L} 1\right.$; line $=$ number of SHB in each colony assuming an equal distribution).

supers were stored outside, attracting robbing bees. In one of them $\left(\mathrm{H}_{F L} 1\right)$, thousands of SHB larvae were crawling on the floor. The possibility of such SHB mass reproduction in honey houses is already well known (Lundie, 1940; Eischen et al., 1999). On the other hand, the honey houses near apiaries with low SHB infestations had high sanitation standards, giving strong support to prudent apicultural practices as means of preventing SHB damage. Besides apicultural structures, environmental factors such as unfavourable soil conditions for SHB pupation (Schmolke, 1974; Ellis et al., 2004b) might limit population growth, thereby influencing infestation levels of different apiaries in the same region.

As expected, regions with high colony losses such as Florida (Neumann and Elzen, 2004) and also recently New South Wales, Australia (Spiewok, 2006), showed the highest infestation levels. In sharp contrast to previously published numbers (4-10 SHB; White, 2004) infestation levels in Australia were surprisingly high (up to $420 \mathrm{SHB}$ ). The relationship between colony losses and infestation levels may result from a positive feedback loop: early SHB mass reproduction in dead colonies and honey houses may lead to a local population boost, resulting in higher parasite pressure on the remaining colonies. Then, subsequent colony collapses maintain or even increase this elevated population level. The lower bee/SHB ratio in Florida compared to Maryland is indicative of such increased parasite pressure. The positive SHB demographic 

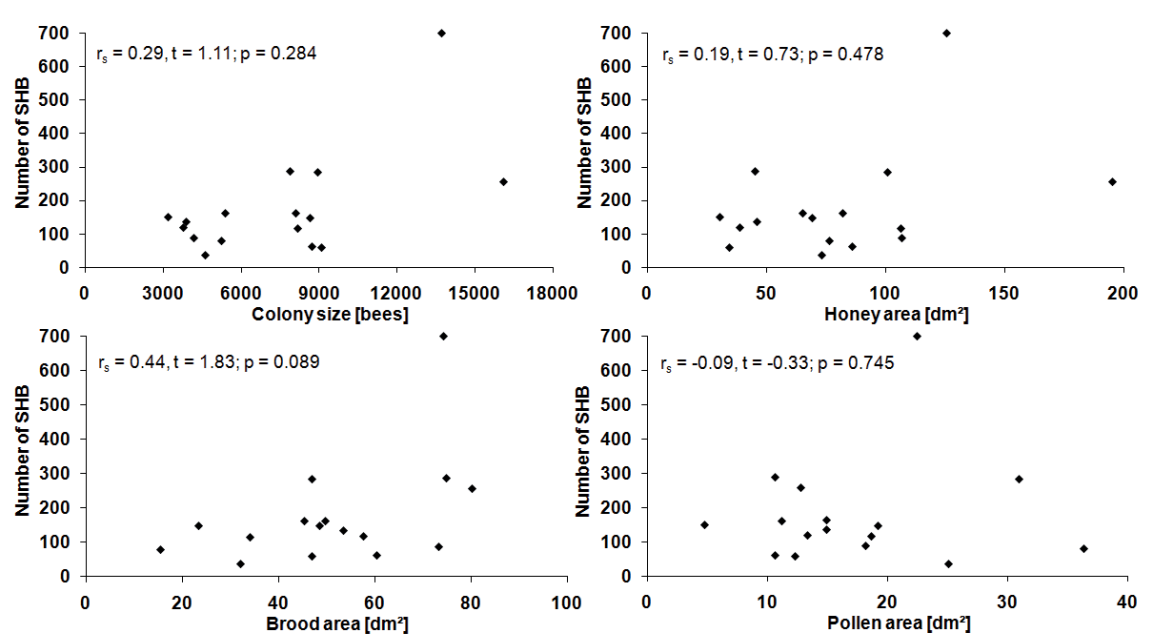

Figure 3. Representative example of colony phenotypes and SHB infestations levels (16 colonies at $\mathrm{H}_{F L} 1$, phenotypes of colonies 17-19 were not determined). No significant regressions were found.

changes in Florida and Australia are typical of strong invaders (Hufbauer and Torchin, 2007). Further possible reasons for the invasive success of SHB are discussed in detail elsewhere (Neumann and Elzen, 2004).

Infestation levels in Maryland and South Africa seem to be too low to cause significant damage to colonies. The low SHB population level in Maryland cannot be explained by the comparatively recent invasion of this state in 2001 (Neumann and Elzen, 2004), because SHB was detected in Australia in the same year (MD unpublished). Consequently, other factors such as climate or local apicultural practices (e.g. apiary density, purpose of honeybee operation, sanitation standards) seem to be responsible for SHB population build-up.

The study was performed in South Africa, Florida and Maryland during summer, but in Australia during spring. However, local Australian beekeepers claim to see more SHB in the colonies in late summer and early autumn compared to spring. Since Australia already showed the highest infestation levels compared to the other regions, the observed relationship between high population level and occurring SHB damage may become even more evident during summer. Therefore, potential seasonal fluctuations in SHB population lev- els (Lundie, 1940; Schmolke, 1974) are unlikely to influence our overall results. Nevertheless, seasonal changes in SHB population levels need to be investigated because knowledge about those fluctuations is important for the IPM decision-making process.

SHB cryptic low level reproduction as reported from European colonies (Spiewok and Neumann, 2006a) was also found in three African colonies. However, only in very few functional colonies were SHB eggs $(0.9 \%)$ or larvae on combs (1.4\%) found, emphasizing that in most infected colonies no SHB offspring are present. African and $\mathrm{Eu}-$ ropean colonies seem to have efficient defensive strategies to prevent SHB reproduction (Ellis et al., 2004a; cf. Neumann and Elzen, 2004; Spiewok and Neumann, 2006b). Despite this, increased parasite pressure due to elevated SHB population levels might overrun colony defences and thus govern colony losses. Therefore adequate preventative measures such as sanitation in honey houses and removal of dead or weak colonies seem to be important in reducing SHB mass reproduction. Colony losses were found in apiaries with average infestation levels of $30 \mathrm{SHB} /$ colony and higher. A healthy colony with only 30 SHB will probably not suffer any damage, but at such an average apiary 
level, SHB may aggregate in higher numbers in single colonies, which may subsequently collapse and boost the local SHB population level. However, even colonies infested by several hundred SHB did not necessarily show any sign of damage. Furthermore, even small colonies with densities as low as ten workers $/ \mathrm{dm}^{2}$ or ratios of only 27 workers/SHB did not show any sign of damage. This is consistent with earlier data, suggesting that the removal of SHB eggs and larvae does not depend on worker density (Spiewok and Neumann, 2006b). Consequently, the determination of a SHB action threshold for IPM seems to be fairly difficult. Other factors as hygienic behaviour, queen quality, simultaneous infestation with other parasites or diseases or beekeeping manipulations may also be responsible for colony collapses, apart from the sheer SHB infestation numbers. Here, we wish to emphasize that recent Australian losses (Spiewok, 2006) clearly show that SHB do not only affect colonies weakened by Varroa destructor, because this ectoparasitic mite does not occur in Australia (Benecke, 2003).

To assess infestation levels our inspection method seems to be reliable because, based on our control data, only a very low proportion of SHB was missed. However, this approach is obviously too labour intensive for practical pest diagnoses. A cheap and easier method is needed to assess the infestation level. We suggest that IPM decisions should be based on SHB infestation levels of whole apiaries as well as individual colonies, due to the high potential for exchange of SHB between colonies. However, more data are needed on the dispersal of SHB and possible seasonal fluctuations of SHB infestation levels before effective IPM strategies can be developed.

\section{ACKNOWLEDGEMENTS}

We would like to thank all beekeepers and local bee inspectors for providing access to their colonies and logistical support. Special thanks to Nelles Ruppert, Sven Buchholz, Katharina Merkel and Sandra Mustafa who helped considerably in the field. Two anonymous reviewers gave very helpful comments to the manuscript. Financial support was granted to PN by the German Federal Ministry for Food, Agriculture and Consumer Protection through the Federal Agency for Agriculture and Food and a visiting fellowship at the University of Western Sydney.

Les populations du Petit coléoptère des ruches, Aethina tumida : taux d'infestation à l'échelle des colonies d'abeilles domestiques, des ruchers et des régions.

\section{Aethina tumida / Apis mellifera / taux infestation / Afrique du Sud / Australie / États-Unis}

\section{Zusammenfassung - Populationen des Kleinen Beutenkäfers Aethina tumida I: Befallszahlen von Bienenvölkern, Bienenständen und Regio-} nen. Der Kleine Beutenkäfer [= SHB], Aethina tumida Murray, kam ursprünglich nur in Afrika südlich der Sahara als Kolonieparasit bzw. Kommensale von Honigbienenvölkern, Apis mellifera, vor. Im Jahr 1996 wurde er jedoch in Nordamerika und 2001 in Australien eingeschleppt. An dieser Stelle veröffentlichen wir die ersten systematischen Daten über Koloniebefallszahlen auf der Basis von 226 Völkern an 31 Bienenständen in Südafrika, Australien, Florida und Australien. Dabei wurden zusätzlich verschiedene Faktoren aufgenommen, welche die Befallszahlen beeinflussen könnten. Innerhalb von Bienenvölkern wurde die Verteilung der SHB durch die Anwesenheit von Bienen beeinflusst, wobei sich in der Abwesenheit von Arbeiterinnen mehr SHB auf den Waben aufhielten. In Afrikanischen Kolonien wurden weniger SHB $(0,1 \%)$ im Brutnest gefunden als in Europäischen Völkern (14\%), was eventuell durch eine aggressivere Verteidigung des Brutnestes durch Afrikanische Arbeiterinnen begründet ist (Tab. II). Die Verteilung von SHB über die Kolonien eines Bienenstandes war signifikant verschieden von einer zufälligen Verteilung (Abb. 2). Allerdings wurde die Attraktivität einer Kolonie nicht durch deren Phänotypen beeinflusst (Größe, Menge an Brut, Pollen oder Honig; Abb. 3; Tab. III). Dies weist darauf hin, dass Kolonievolatile von SHB wahrscheinlich zur Orientierung jedoch nicht zur Diskriminierung zwischen Wirten genutzt werden. Bienenstände neben großen Honey Houses (Imkerschuppen im größeren Stil) zeigten erhöhte Befallszahlen, die wahrscheinlich durch dortige Massenreproduktion des Käfers verursacht wurden (Abb. 1; Tab. I). Regionen, in denen SHB mehr Schäden anrichten (Australien und Florida) wiesen höhere SHB-Populationszahlen auf (Tab. I). Unterschiede im Parasitendruck durch erhöhte SHB-Populationszahlen könnten daher für die höheren Völkerverluste in den entsprechenden Regionen mitverantwortlich sein. Folglich scheinen Methoden, welche die Käferpopulation innerhalb eines Bienenstandes reduzieren (z.B. das 
Entfernen von toten Völkern und ein sauberes Arbeiten) besonders wichtig für die erfolgreiche Kontrolle des Kleinen Beutenkäfers zu sein.

\section{Aethina tumida / Apis mellifera / Kleiner Beuten- käfer / Befallszahlen / Honigbiene}

\section{REFERENCES}

Bartelt R.J. (1999) Sap beetles, in: Hardie J., Minks A.K. (Eds.), Pheromones of non-lepidopteran insects associated with agricultural plants, CABI publishing, Wallingford, pp. 69-89.

Benecke F.S. (2003) Commercial Beekeeping in Australia. A report for the rural industries research and development corporation. RIRDC Publication No. 03/037. RIRDC, Barton, ACT, Australia.

Binns M.R., Nyrop J.P. (1992) Sampling insect populations for the purpose of IPM decision making, Annu. Rev. Entomol. 37, 427-453.

Eischen F.A., Westervelt D., Baxter J. (1999) Small hive beetles in the honey house! Am. Bee J. 139, 934-935.

Ellis J.D., Delaplane K.S. (2006) The effects of habitat type, ApilifeVAR, and screened bottom boards on small hive beetle (Aethina tumida) entry into honey bee (Apis mellifera) colonies, Am. Bee J. 146, 537-539.

Ellis J.D., Delaplane K.S., Richards C.S., Hepburn R., Berry J.A., Elzen P.J. (2004a) Hygienic behaviour of Cape and European Apis mellifera (Hymenoptera: Apidae) toward Aethina tumida (Coleoptera: Nitidulidae) eggs oviposited in sealed brood cells, Ann. Entomol. Soc. Am. 97, 860-864.

Ellis J.D., Hepburn H.R., Luckmann B., Elzen P.J. (2004b) The effects of soil type, moisture, and density on pupation success of Aethina tumida (Coleoptera: Nitidulidae), Environ. Entomol. 33, 794-798.

Elzen P.J., Baxter J.R., Westervelt D., Randall C., Delaplane K.S., Cutts L., Wilson W.T. (1999) Field control and biology studies of a new pest species, Aethina tumida Murray (Coleoptera, Nitidulidae) attacking European honey bees in the Western hemisphere, Apidologie 30, 361-366.

Elzen P.J., Baxter J.R., Westervelt D., Randall C., Wilson W.T. (2000) A scientific note on observations of the small hive beetle, Aethina tumida Murray (Coleoptera, Nitidulidae) in Florida, USA, Apidologie 31, 593-594.

Elzen P.J., Baxter J.R., Neumann P., Solbrig A., Pirk C.W.W., Hepburn H.R., Westervelt D., Randall C. (2001) Behaviour of African and European subspecies of Apis mellifera toward the small hive beetle, Aethina tumida, J. Apic. Res. 40, 40-41.

Elzen P.J., Westervelt D., Ellis J.D., Hepburn H.R., Neumann P. (2002) Method of application of tylosin, an antibiotic for American foulbrood control, with effects on small hive beetle (Coleoptera:
Nitidulidae) populations, J. Econ. Entomol. 95, $1119-1122$.

Hufbauer R.A., Torchin M.E. (2007) Integrating ecological and evolutionary theory of biological invasions, in: Nentwig W. (Ed.), Biological invasions, Springer Verlag, Berlin, pp. 79-96.

Imdorf A., Buehlmann G., Gerig L., Kilchenmann V., Wille H. (1987) Überprüfung der Schätzmethode zur Ermittlung der Brutfläche und der Anzahl Arbeiterinnen in freifliegenden Bienenvölkern, Apidologie 18, 137-146.

Lundie A.E. (1940) The small hive beetle Aethina tumida, Science Bulletin 220, Dep. Agr. Forestry, Government Printer, Pretoria.

Martin S.J. (2001) The role of Varroa and viral pathogens in the collapse of honeybee colonies: a modelling approach, J. Appl. Ecol. 38, 10821093.

Neumann P., Elzen P.J. (2004) The biology of the small hive beetle (Aethina tumida Murray, Coleoptera: Nitidulidae): Gaps in our knowledge of an invasive species, Apidologie 35, 229-247.

Person H.L. (1931) Theory in explanation of the selection of certain trees by the western pine beetles, J. For. 29, 696-699.

Schmolke M.D. (1974) A study of Aethina tumida: the small hive beetle, Project Report, University of Rhodesia.

Spiewok S. (2006) Kleiner Beutenkäfer in Australien - Imkern mit einer neuen Plage, Deutsches Bienenjournal 14, 14-15.

Spiewok S., Neumann P. (2006a) Cryptic low-level reproduction of small hive beetles in honeybee colonies, J. Apic. Res. 45, 47-48.

Spiewok S., Neumann P. (2006b) The impact of queenloss and colony phenotypes on the removal of small hive beetle (Aethina tumida Murray) eggs and larvae by African honeybee colonies (Apis mellifera capensis Esch.), J. Insect Behav. 19, 601-611.

Suazo A., Torto B., Teal P.E.A., Tumlinson J.H. (2003) Response of the small hive beetle (Aethina tumida) to honey bee (Apis mellifera) and beehiveproduced volatiles, Apidologie 34, 525-533.

Thalenhorst W. (1958) Grundzüge der Populationsdynamik der großen Fichtenborkenkäfer Ips typographus L. Sauerlaender, Frankfurt a. M.

Torto B., Suazo A., Alborn H., Tumlinson J.H., Teal P.E.A. (2005) Response of the small hive beetle (Aethina tumida) to a blend of chemicals identified from honeybee (Apis mellifera) volatiles, Apidologie 36, 523-532.

Torto B., Boucias D.G., Arbogast R.T., Tumlinson J.H., Teal P.E.A. (2007) Multitrophic interaction facilitates parasite-host relationship between an invasive beetle and the honey bee, Proc. Natl. Acad. Sci. USA 104, 8374-8378.

Tribe G.D. (2000) A migrating swarm of small hive beetles (Aethina tumida Murray), S. Afr. Bee J. 72, 121-122.

White B. (2004) Small hive beetle (Notes), Apiacta 38, 295-301. 